\title{
Resultados funcionais da artrodese do punho
}

\author{
Functional results of wrist arthrodesis
}

\section{RESUMO}

São analisados os resultados funcionais 51 artrodeses do punho em 49 pacientes, portadores de variadas patologias dessa região. Em todos os casos, a artrodese foi realizada com fixação interna rígida, usando placa e parafusos e o seguimento pósoperatório variou de 6 a 201 meses (média: 73 meses). Para a avaliação funcional foi empregado um método de subjetivo, baseado nas impressões dos próprios pacientes, e outro objetivo, através da análise das radiografias e de testes funcionais que simulam todo tipo de função do membro superior.

A posição de fixação da artrodese foi de $14^{\circ}$ de extensão e $8^{\circ}$ de desvio ulnar, em média. Consolidação primária foi obtida em 50 (98\%) punhos, num período médio de oito semanas, sendo que, no punho restante ocorreu pseudartrose, consolidada após re-operação com enxertia óssea. Houve melhora da intensidade e mudança do padrão da dor pré-operatória e todos os pacientes com atividade leve retornaram ao trabalho. . Houve perda relativa da força de preensão manual (61\% do contralateral) e das pinças (cerca de $70 \%$ do lado contralateral), porém os testes funcionais apresentaram resultados considerados satisfatórios e concordantes com a literatura. Conclui-se que a artrodese do punho é um método aplicável a diversas patologias que impliquem em dor e instabilidade da articulação, que produz resultados consistentemente repetitíveis, sem afetar significativamente a função global do membro superior, apesar da relativa perda da força, a qual se deveu mais a fatores pré-existentes do que a artrodese em si.

Descritores: Punho; artrodese; resultados funcionais

\section{INTRODUÇÃO}

O uso funcional da mão, quer em atividades de força ou de precisão, depende de um punho estável e indolor. A instabilidade

\section{SUMMARY}

The functional results of 51 wrist arthrodesis carried out in 49 patients with different regional pathologies are analyzed. In all cases the arthrodesis was performed with rigid internal fixation with a dynamic compression plate; postoperative follow-up ranged from 6 to 201 months (average: 73 months). Both subjective and objective methods were used in the evaluation. The subjective method was based on the evaluation by the patients and the objective method on analysis of radiographs and functional tests simulating all different functions of the upper limb.

The arthrodesis was performed in $14^{\circ}$ extension and $8^{\circ}$ ulnal deviation, on average. Primary healing was obtained in 50 wrists (98\%) in eight weeks on average. Pseudarthrosis was observed in one single case, and eventually healed after reoperation for bone grafting. All patients presented pain improvement, with a different pattern, as compared to the preoperative period and all of those with lighter activities resumed their previous occupation. Relative loss of grip strength (61\% from normal) and digital pinch (70\% from normal) were observed, but final results were considered as satisfactory on the functional tests, in accordance to the literature. It was concluded that wrist arthrodesis is applicable to a diversity of wrist pathologies which imply in pain and unstability, with easily reproducible results, without significantly affecting the global upper limb function, despite the relative loss of power, mainly due to the pre-existing factor.

Key words: Wrist; arthrodesis; functional results

\section{INTRODUCTION}

Functional use of the hand, either in strength or precision activities, is dependent on an stable and not painful wrist. Instability and pain result in prejudiced function and require some treatment, usu-
*Trabalho realizado no Serviço de Cirurgia da Mão e do Membro Superior e Microcirurgia, Hospital das Clínicas da Faculdade de Medicina de Ribeirão Preto - USP

1 - Professor titular

3 - Terapêuta ocupacional

2- Professor associado 4- Fisioterapêuta

Endereço para correspondência: Serviço de Cirurgia da Mão e do Membro Superior e Microcirurgia,Hospital das Clínicas da Faculdade de Medicina de Ribeirão Preto USP - Campus Universitário - 14048-900 Ribeirão Preto SP BRASIL
Work performed at Hand and Upper Limb Surgery Service and Microsurgery from Hospital das Clínicas da Faculdade de Medicina de Ribeirão Preto - USP

1- Chairman

3- Ocupational therapist

2- Associate Professo

4- Physiotherapist

Adress: Hand and Upper Limb Surgery and Microsurgery Service, Hospital das Clínicas da Faculdade de Medicina de Ribeirão Preto - USP Campus Universitário - 14048-900 Ribeirão Preto SP BRASIL 
e a dor implicam em prejuízo da função e requerem alguma forma de tratamento, em geral cirúrgico(21). Distúrbios localizados da articulação rádio-cárpica podem ser tratados por meio de técnicas operatórias que envolvem a reconstrução ligamentar, a artrodese intracarpal limitada e a carpectomia da fileira proximal, as quais promovem graus variados de estabilidade e alívio da dor, com a vantagem de manter alguma mobilidade do punho(18,22). Já nas instabilidades e artroses carpais graves e no insucesso dos procedimentos anteriormente citados, a artrodese total do punho tem seu espaço como um procedimento de salvação(6).

As indicações mais frequentes para artrodese total do punho são as patologias carpais restritas (p.e., doença de Kienböck), as patologias carpais totais (p.e., as seqüelas pós-trauma, artrite reumatóide e outras) e as patologias extra-carpais (p.e., doenças neuromusculares, lesões de partes moles peri-articulares e ressecções tumorais) $)^{(19)}$.

Muitas técnicas têm sido descritas para a realização da artrodese do punho, envolvendo a utilização de vários recursos de osteossíntese, como fios cruzados, fios intramedulares e placas e parafusos, associados ou não ao emprego de enxerto ósseo(1,5). Cada um desses métodos apresenta vantagens e desvantagens inerentes, mas a fixação interna rígida com placa e parafusos dispensa o uso de um tutor externo durante todo o período de consolidação, possibilitando a reabilitação precoce, sem o risco de perda das correções obtidas $(2,7,15,17)$.

Embora produza como resultado um punho indolor e estável, a artrodese do punho ainda é motivo de controvérsia no que se refere à função global do membro afetado. Por isso, a avaliação funcional deve ser feita por meio de um método de fácil execução, aceitação universal e que contenha parâmetros objetivos e subjetivos que facilitem a comparação de resultados, sendo, portanto, reprodutível por qualquer pesquisador ${ }^{(4,10)}$.

O propósito do presente estudo foi avaliar a eficácia da fixação interna rígida como método de artrodese do punho e a função global do membro superior após consolidação da artrodese.

\section{MATERIAL E MÉTODOS}

No período de 7 de março de 1983 a junho de 1999, 49 pacientes (51 punhos) foram submetidos à cirurgia de artrodese do punho com uso de fixação interna rígida por meio de placa e parafusos. Vinte e nove pacientes eram homens e vinte, mulheres, com idade variando de 18 a 70 anos (média: 42,06 anos). Dos 51 punhos operados, 28 eram direitos e 23 eram esquerdos, sendo que em 26 casos o lado operado era o dominante.

As principais indicações para a artrodese do punho foram a incapacidade funcional, presente em 46 pacientes (93,87\%), e a dor aos movimentos, presente em 36 pacientes $(73,46 \%)$, sendo que 30 pacientes $(61,22 \%)$ apresentavam também dor em repouso. No concernente ao tipo, predominaram os casos de patologia carpal total, incluindo os colapsos carpais por fratura do escafóide(7), as degenerações rádio-carpais por fratura da extremidade distal do rádio (5), artropatias sistêmicas(5) e disjunção escá- ally surgical(21). Localized derangement of radio carpal joint may be treated by means of operative techniques invo/ving ligamental reconstruction, limited intra carpal arthrodesis, and proximal line carpectomy, which bring different degrees of stability and pain relief, with the advantage of keeping some wrist mobility ${ }^{(18,22)}$. Yet in severe instability and carpal arthrosis, and in cases where the previously mentioned procedures failed, total wrist arthrodesis has a room as a salvation procedure(6).

Most frequent indications for total wrist arthrodesis are the restricted carpal pathologies (e.g. Kienböck's disease), and total carpal pathologies (e.g., post traumatic sequelae, rheumatoid arthritis and others) and extra carpal pathologies (e.g., neuromuscular diseases, periarticular soft tissue injuries, and tumoral ressections)(19).

Many techniques were described for performing wrist arthrodesis, involving different fixation devices, as crossed wires, intramedullary wires, plates and screws, associated or not to bone grafting ${ }^{(1,5)}$. Each one of these methods brings inherent advantages and disadvantages, however, rigid internal fixation with plate and screws avoids the use of external splint during the healing period, allowing an early rehabilitation without risk of loosing the achieved corrections ${ }^{(2,}$ $7,15,17)$.

Even resulting in a wrist that is stable and not painful, wrist arthrodesis is still controversial in relation to global function of the affected limb. For this reason, functional activity evaluation should be performed by means of a easily performable method, universally accepted, and involving both objective and subjective parameters, making easier result comparison thus being reproducible by any investigator ${ }^{(4,10)}$.

The objective of this study was to evaluate the efficacy of rigid internal fixation as a wrist arthrodesis method, and the global function of the upper limb after the arthrodesis healed.

\section{MATERIAL AND METHODS}

Between March $7^{\text {th }}, 1983$ and June, 1999, 49 patients (51 wrists) underwent wrist arthrodesis using internal fixation by means of plate and screws. They were 29 males and 20 women, and age ranged from 18 to 70 years old (average: 42.06 years). Right side was involved in 51 wrists, and left in 23. In 26 cases, it was operated the dominant side.

The most important indication for arthrodesis was functional impairment, in 46 patients (93.87\%), and pain on movements, observed in 36 patients (73.46\%). Thirty patients (61.22\%) had also pain at rest. Regarding the ethiology, total carpal pathology was predominant, including carpal colapse due to scaphoid fracture ${ }^{(7)}$, radiocarpal degeneration due to distal radius fracture ${ }^{(5)}$, systemic arthropaties ${ }^{(5)}$ and scapho-lunal disjunction ${ }^{(3)}$, with a total of 20 cases. Restrict carpal pathologies followed, involving exclusively Kiemböck's disease, with a total of 17. Last came extracarpal pathologies, with a total of 12 (Table 1).

\section{Operative Technique}

Under regional anesthesia of the brachial plexus (59\%), or inhalatory general anesthesia (29\%), or combined (12\%), the affected wrist was approached through a dorsal longitudinal incision, opening 
fo-lunar (3), totalizando 20 casos. Seguiram-se os casos de patologia carpal restrita, preenchidos exclusivamente por casos de doença de Kienböck, que somaram 17. Depois, vieram as patologias extracarpais, no total de 12 casos (Tabela 1).

\section{Técnica Operatória}

Sob anestesia regional do plexo braquial (59\%), geral inalatória (29\%) ou combinada (12\%), o punho afetado era abordado através de incisão longitudinal dorsal, com abertura do retináculo extensor, entre o $3^{\circ}$ e $4^{\circ}$ túneis. A capsula articular era igualmente aberta no sentido longitudinal e rebatida lateral e medialmente, e o tubérculo de Lister era ressecado. A cartilagem das superfícies articulares entre o rádio, escafóide, semilunar e capitato eram removidas cuidadosamente, com osteotómos delicados e curetas, evitando-se a ressecção excessiva do osso esponjoso subcondral.

A fixação interna rígida foi realizada em 47 casos (92\%) com o uso de uma placa de compressão dinâmica (DCP) de $3,5 \mathrm{~mm}$, segundo a técnica recomendada pela $A O^{(8,15)}$. Alternativamente, foi empregada uma placa semitubular de $3,5 \mathrm{~mm}$, em quatro casos (8\%). A placa era fixada primeiro no rádio e depois no segundo metacárpico (sete casos) ou no terceiro (44 casos). Enxerto ósseo homólogo foi empregado em 26 casos (51\%), tendo sido proveniente da crista ilíaca anterior (12), cabeça da ulna ressecada (8) ou extremidade distal do rádio (6). A cabeça da ulna foi ressecada em oito casos, devido a alterações degenerativas associadas da articulação rádio-ulnal distal, como é relatado na literatura ${ }^{(6)}$; alternativamente, foi realizada a operação de Sauvé-Kapandji em outros dois casos, de imediato em um com alterações degenerativas difusas do punho, e tardia no outro, com síndrome de impacto ulno-carpal desenvolvido após a realização da artrodese do punho ${ }^{(14)}$.

\section{Seguimento pós-operatório}

Tala gessada foi empregada até a retirada dos pontos, ao redor do décimo dia, quando se iniciava o tratamento fisioterápico com mobilização dos dedos e cotovelo, sendo descontinuado o uso de imobilização externa após este periodo. Controles radiológicos eram feitos mensalmente até a evidência da consolidação óssea. A retirada do material de síntese foi realizada de rotina em 11 casos ( média: 11,72 meses) e condicionada à presença de dor crônica pós-operatória em 5 casos, variando de 7 a 50 meses após a artrodese (média:33,82 meses), o que totaliza 16 casos de retirada da placa e parafusos $(31,37 \%)$. O tempo de seguimento médio dos pacientes foi de 73 meses, variando de 6 a 201 meses. the extensor retinaculum between $3^{\text {rd }}$ and $4^{\text {th }}$ tunnels. Articular capsule was as well longitudinally opened and retracted medially, ressecting the Lister tuberculus. Articular cartilage of radius, scaphoid, lunate and capitate were carefully removed, avoiding excessive removal of subcondral cancellous bone.

Rigid internal fixation was performed in 47 cases (92\%) using a $3.5 \mathrm{~mm}$ dynamic compression plate (DCP), according to $A O$ recommended technique ${ }^{(8,15)}$. Alternatively a $3.5 \mathrm{~mm}$ semi-tubular plate was used in four cases (8\%). The plate was initially screwed to radius and after to the second metacarpal (7 cases) or to the third metacarpal (44 cases). Homologous bone grafting was used in 26 cases (51\%), from anterior iliac crest (12), resected ulnal head (8) or radial distal extremity (6). Ulnal head was removed in 8 cases, due to degenerative changes associated to distal radio-ulnal joint, as reported in literature (6); alternativelly, Sauvé-Kapandji operation was performed in two other cases, in one with immediate diffuse degenerative wrist changes, and late in the other one, with ulno-carpal impact syndrome developed after wrist arthrodesis was performed (14)

\section{Postoperative Follow-up}

A cast splint was used until stitches were removed, around the tenth day, when physiotherapy was started moving fingers and elbow, and external immobilization abandoned after this period. Radiographic control was monthly performed until bone healing was documented. Removal of synthesis material was routinely performed in 11 cases (average 11.72 months) and due to chronic postoperative pain in 5 cases, ranging from 7 to 50 months after the arthrodesis was performed (average: 33.82 months), with a total of 16 cases of plate and screws removal (31.37\%). Average follow-up of these patients was 73 months, ranging form 6 to 201 months.

\section{Subjective Evaluation}

Patients were requested to perform a subjective evaluation of the pain they had preoperatively, rating it according to scores 1 to 4 (1 - no pain; 2 - light and occasional pain; 3 - moderate pain; 4 severe pain), and to compare it to eventual postoperative pain. Patients were as well questioned regarding their satisfaction, using a score system 1 to 3 (1- completely satisfied; 2-partially satisfied; 3 -dissatisfied) and as if they returned or not to their usual professional activities.

\section{Objective Evaluation}

Preoperative radiographs were evaluated in all patients in antero-posterior and lateral aspects, regarding the following parameters: radio-carpal relation, radio-ulnal relation, carpal collapse, nar- 


\section{Avaliação Subjetiva}

Os pacientes foram solicitados fazer uma avaliação subjetiva da dor que tinham no período pré-operatório, graduando-a segundo um sistema de escores de 1 a 4 (1- sem dor; 2- dor leve e ocasional; 3- dor moderada; 4- dor severa), e comparando-a com a dor eventual no período pós-operatório. Foram também indagados quanto à satisfação, utilizando um sistema de escores de 1 a 3 (1- satisfação completa; 2- satisfação parcial; 3- insatisfeito) e quanto ao retorno ou não às atividades profissionais.

\section{Avaliação Objetiva}

Foram examinadas as radiografias pré-operatórias do punho nas vistas ântero-posterior e perfil de todos os pacientes, observando-se os seguintes parâmetros: relação rádio-cárpica, relação rádio-ulnar, colapso carpal, diminuição do espaço articular, erosão da superfície articular e presença de osteófitos. Nas radiografias pós-operatórias, foram avaliados a posição de fixação do punho e o tempo de consolidação.

A avaliação funcional incluiu o teste de força de preensão global dos dedos e das três pinças digitais (polpa-polpa, lateral e três pontos), a goniometria e os testes funcionais de Jebsen e de Buck-Gramcko, este último específico para avaliação da artrodese. Os testes de força muscular foram efetuados utilizando-se um dinamômetro para preensão manual ${ }^{\star}$ e um pinchmeter para as pinças $^{* *}$, com três aferições alternadas, tomando o membro contralateral como referência, para comparação. Na goniometria, foram avaliados comparativamente a flexo-extensão, o desvio radio-ulnar e a prono-supinação.

O teste de Jebsen envolve uma série de simulações de tarefas cotidianas, como escrever, alimentar-se e pegar objetos, tais como cartões, objetos pequenos, leves e pesados.. O escore percentual é obtido à partir de valores padronizados em estudos-controle efetuados pelo próprio autor. O teste de Buck-Gramcko faz uma avaliação objetiva da artrodese, conforme visto na (Tabela 2).

\section{RESULTADOS}

Dos 49 pacientes submetidos à artrodese do punho, 32 compareceram para entrevista e foram submetidos à análise funcional pós-

\begin{tabular}{ccccc}
\hline \multirow{2}{*}{$\begin{array}{c}\text { Dor pré-operatória } \\
\text { Dor pós-operatória }\end{array}$} & sem dor & leve & moderada & intensa \\
\cline { 3 - 5 } & 10 & 2 & 5 & 15 \\
Satisfação & 19 & 7 & 3 & 3 \\
\cline { 3 - 5 } & & completa & parcial & insatisfeito \\
\cline { 3 - 5 } & & 26 & 5 & 1 \\
\cline { 3 - 4 } & Retorno às atividades & & sim & não \\
\hline
\end{tabular}

Tabela 3 - Avaliação subjetiva dos resultados. Table 3 - Subjective evaluation of the results. rowing of articular space, articular surface erosion, and presence of osteophytes. In postoperative radiographs were evaluated fixation position of the wrist and time to bone healing.

Functional evaluation included the global finger grip strength and of the three digital pinches (pulp-pulp, lateral and three points), goniometry, and Jebsen and Buck-Gramcko functional tests, this last, specific for arthrodesis evaluation. Muscular strength tests were performed using a hand grip dynamometer* and a pinchmeter for the pinches ${ }^{* *}$, with three alternated measurements, using contralateral limb as a reference for comparisons. In goniometry were comparatively evaluated: flexoextension, radio-ulnal deviation and prono-suppination.

Jebsen test involves a series of daily life tasks simulation, such as writing, feeding and taking objects like cards, small objects, light and heavy. Percentual score is obtained from pattern values obtained in control studies by the author. BuckGramcko test performs an objective evaluation of arthrodesis, as seen in (Table 2).

\section{RESULTS}

From the 49 patients who underwent wrist arthrodesis, 32 returned for interview and underwent a postoperative functional analysis (Table 3). For the remaining 17 patients, who did not return for the evaluation, arthrodesis result was evaluated by the files and radiographs.

\section{Subjective Evaluation}

An overall improvement of the pain, both in intensity and pattern, was observed. However, from the 20 cases with preoperative severe or moderate pain (62.5\%), 6 (27.27\%) had the same pattern and intensity level after the surgery according to subjective information. On the other side, the number of patients without pain or with light pain changed from 12 (37.5\%) to 26 (81.2\%).

Complete or partial satisfaction was obtained in 31 patients (96.8\%). Reason for dissatisfaction, in the only case that reported such, was pain due to plate loosing, leading to indication for a surgical revision of the arthrodesis.

Heavy duty workers, such as sugar cane croppers, stone masons or 
operatória (Tabela 3). Para os 17 pacientes que não compareceram, o resultado da artrodese foi avaliado através da análise dos prontuários e radiografias.

\section{Avaliação Subjetiva}

Houve melhora generalizada da dor, quer quanto à intensidade ou ao padrão, mas dos 20 casos com dor intensa ou moderada $(62,5 \%)$ no pré-operatório, seis $(27,27 \%)$ mantiveram praticamente o mesmo padrão e o mesmo nível no pós-operatório, segundo informação subjetiva. Por outro lado, o número de pacientes sem dor ou com dor leve passou de $12(37,5 \%)$ para 26 $(81,2 \%)$.

Satisfação completa ou parcial foi obtida em 31 pacientes $(96,8 \%)$. O motivo da insatisfação no único paciente que assim se declarou foi a dor ocasionada pela soltura da placa, para o que foi indicado refazer a artrodese.

Pacientes trabalhadores braçais, como cortadores de cana, pedreiros ou encanadores não conseguiram retornar às atividades profissionais prévias, principalmente devido à perda de força de preensão manual e à dor aos esforços. Entretanto, a dor surgia caracteristicamente nas atividades que exigiam movimentos de prono-supinação, praticamente não se manifestando aos esforços axiais. Já os pacientes com atividades leves voltaram todos ao trabalho sem restrições $(65,62 \%$ do total).

\section{Avaliação Objetiva}

A observação das radiografias pré-operatórias dos 49 pacientes (51 punhos) evidenciou a presença de artrose intracarpal, principalmente entre o escafóide, o semilunar e o capitato, em 29 casos (59,18\%). Colapso carpal foi pesquisado nos punhos acometidos por doença de Kienböck (Figuras 2 e 3) ou pseudo-artrose do escafóide, utilizando-se
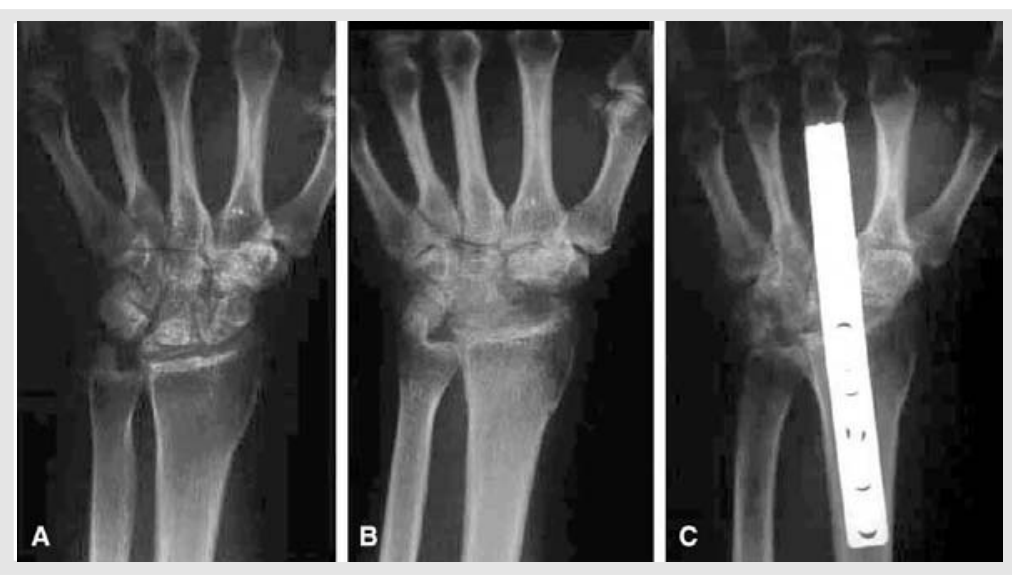

Figura 2 - Paciente com Doença de Kienböck. A) Radiografia préoperatória mostrando o colapso carpal e artrose radiocárpica; B) Resultado da operação de ressecção da primeira fileira do carpo, com o paciente muito sintomático; C) Artrodese do punho, fixada com placa DCP.

Figure 2 - Patient with Kiemböck's disease. A) Preoperative radiograph displaying carpal collapse and radiocarpal arthrosis. B) Result of first carpal line removal with a very symptomatic patient; C) Wrist arthrodesis, with fixation by a DCP plate. plumbers, couldn't go back to their usual professional activities, mostly due to lack of hand grip strength and pain when under effort. However, pain clearly appeared in activities requesting prono-suppination, barely appearing in axial efforts. Yet patients with lighter activities returned to usual work with no restriction (65.62\% of the total).

\section{Objective Evaluation}

Evaluation of preoperative radiographs of the 49 patients (51 wrists) evidenced intracarpal arthrosis, mainly between scaphoid, lunate and capitate in 29 cases (59.18\%). Carpal collapse was screened in wrists enböck's disease (Figures 2 and 3) or scaphoid pseudarfound in 14 cases of the 24 wrists with those pathologies (58.33\%). Degeneration of distal radio-ulnal joint or the presence of the "ulna radio-carpal space in 29 cases (59.18\%) and presence of osteo-

Radiographic analysis demonstrated that the arthrodesis position was in average in $14.2^{\circ}$ extension (range $0^{\circ}$ to $32^{\circ}$ ), and $8.7^{\circ}$ in average 8.16 weeks, ranging form 6 to 16 weeks.

Hand grip strength was, in average of $61.21 \%$ of normal contralateral side, ranging from 7.2 to $100 \%$, being the lesser values observed in extracarpal pathologies, mainly neuromuscular (average: $52.27 \%)$. Pinches strength was slightly higher than hand grip, being in average $64.11 \%$ for lateral pinch, $71.66 \%$ for pulp-pulp and $71.40 \%$ for three point pinch, in comparison to contralateral side.

In goniometry, a pronosuppination deficit was found, with an average of $75.58^{\circ}$ pronation, and $64.77^{\circ}$ suppination, however not configuring functional impairment for daily activities.

Under Jebsen method functional evaluation, it was found that function of wrists 
o método da altura carpal de MacMurtry(4), tendo sido encontrados em 14 casos dos 24 punhos com aquelas patologias (58,33\%). A degeneração da articulação radio-ulnar distal ou presença da variante "ulna minus" foram encontradas em 3 casos. Foram também notadas a diminuição do espaço articular rádio-cárpico em 29 casos (59,18\%) e a presença de osteofitos em 25 casos (51,02\%).

A análise radiográfica mostrou que a posição de fixação da artrodese ficou, em média, em $14,2^{\circ}$ de extensão (variação: $0^{\circ}$ a $32^{\circ}$ ) e $8,7^{\circ}$ de desvio ulnar (variação: $0^{\circ}$ a $22^{\circ}$ ) (Figura 3). O de tempo consolidação foi, em média, de 8,16 semanas, variando de 6 a 16 semanas.

A força de preensão manual foi, em média, de $61,21 \%$ do lado contralateral normal, variando de 7,2 a $100 \%$, sendo que os menores valores foram observados em patologias extracarpais, principalmente as neuromusculares (média: 52.27\%). A força das pinças foi discretamente maior que a de preensão, tendo sido, em média de $64,11 \%$ para a pinça lateral, $71,66 \%$ para a polpa-polpa e $71,40 \%$ para a de três pontos, em relação ao lado contralateral.

Na goniometria, foi observado um déficit na prono-supinação dos punhos acometidos, com média de $75,58^{\circ}$ de pronação e $64,77^{\circ}$ de supinação, o que entretanto não configurou limitação funcional para as atividades diárias.

À avaliação funcional pelo método de Jebsen, observou-se que a função dos punhos artrodesados era em média de 50,73\% do percentil-padrão determinado por aquele autor, ao passo que nos punhos normais era de $70,75 \%$, representando uma função relativa média de $71,70 \%$ nos punhos operados. A avaliação individual das tarefas podem ser vistas na (Figura 1).

No teste de Buck-Gramcko, a pontuação média final foi de 6,79 , que eqüivale a um resultado satisfatório. A avaliação em separado, por tipo de patologia, mostrou que as patologias extra-carpais, carpais restritas e carpais totais atingiram pontuação de 5,12 (satisfatório), 7,33 (bom) e 8,00 (bom), respectivamente.

\section{Complicações}

Cinco pacientes apresentaram infecção superficial da ferida cirúrgica e foram tratados com antibioticoterapia, evoluindo com cura sem a necessidade de desbridamento cirúrgico. Um paciente apresentou síndrome do túnel do carpo após a artrodese, que foi resolvida com a liberação do retináculo flexor do punho. Três pacientes necessitaram revisão da artrodese, respectivamente

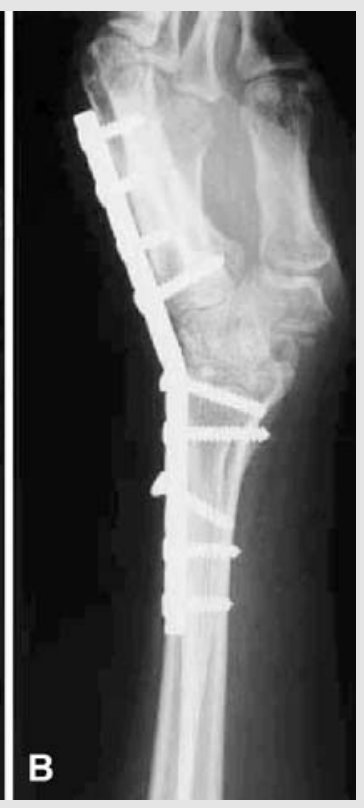

that underwent arthrodesis was in average $50.73 \%$ of the pattern percentile determined by the author, while in normal wrists was $70.75 \%$, representing a relative average function of $71.70 \%$ in operated wrists. Individual evaluation of the tasks may be seen in (Figure 1).

In Buck-Gramcko test, average final rate was 6.79, equivalent to a satisfactory result. Separated evaluation, by pathology demonstrated that extracarpal pathologies, restricted carpal pathologies and total carpal pathologies, reached the scores 5.12 (satisfactory), 7.33 (good) and 8.00 (good), respectively.

\section{Complications}

Five patients presented superficial infection of surgical wound, were treated with antibiotics and healing was achieved without need of surgical débridement. One patient had carpal tunnel syndrome after the arthrodesis, which was resolved by flexor retinaculum liberation. Three patients needed to be submitted to arthrodesis revision, due to loosening of synthesis material, plate fracture and pseudarthrosis. Five patients had chronic post operative pain, making necessary to remove the plates and screws.

\section{DISCUSSION}

Wrist mobility loosening consequent to arthrodesis leads some surgeons to consider this procedure as the last treatment for a series of intra-articular and extra-articular conditions. However, the disability produced by wrist arthrodesis may be compensated, or alleviated, since the patient has normal shoulder, elbow, forearm and hand ${ }^{(3,9)}$.

Subjective evaluation of the studied cases demonstrated that wrist arthrodesis was efficacious for reducing pain intensity and changing its pattern. However, in 6 cases (18.75\%) pain persisted in daily activity, what was reported by other authors ${ }^{(22)}$, who found recurrence of pain in $5.6 \%$ of their cases and by ${ }^{(12,13)}$, with $11 \%$ of pain recurrence. Besides this, patients' satisfaction with the method is high, reaching $96.8 \%$ among our patients, who related it to pain improvement, wrist stability and adequate hand positioning. On the other hand, despite the high index of satisfaction, only $65.2 \%$ of the patients returned to their previous professional activity, even those considered as light. Patients working in heavy duties didn't go back to their jobs, particularly prejudiced by pain on pronation and suppination efforts.

Position of the arthrodesed wrist was extension (average: $14.2^{\circ}$ ) and ulnal deviation (average $8.7^{\circ}$ ), within the adequate range for 
por soltura do material de síntese, fratura da placa e pseudartrose. Cinco pacientes evoluiram com dor crônica pós-operatória, sendo necessária a retirada da placa e parafusos.

\section{DISCUSSÃO}

A perda de mobilidade do punho decorrente da artrodese faz com que alguns cirurgiões considerem este procedimento como o último recurso para o tratamento de uma série de patologias intrarticulares e extrarticulares. Porém, a incapacidade produzida pela artrodese do punho pode ser compensada ou minorada, desde que o paciente tenha o ombro, cotovelo, antebraço e a mão normais ${ }^{(3,9)}$

A avaliação subjetiva dos casos aqui estudados revelou que a artrodese do punho foi eficaz para diminuir a intensidade da dor e mudar o seu padrão. Todavia, em 6 casos $(18,75 \%)$ houve persistência da dor nas atividades diárias, fato que foi referido por outros autores ${ }^{(22)}$, que observaram recorrência da dor em 5,6\% dos seus casos, e por ${ }^{(12,13)}$, com $11 \%$ de recorrência da dor. Apesar disso, a taxa de satisfação dos pacientes com o procedimento é alta, tendo atingido $96,8 \%$ nos nossos pacientes, que a relacionaram à melhora da dor, à estabilidade do punho e ao posicionamento adequado da mão. Por outro lado, a despeito da alta taxa de satisfação, apenas $65,2 \%$ dos pacientes retornaram às atividades profissionais prévias, mesmo assim àquelas consideradas leves. Os pacientes que exerciam atividades pesadas não retornaram ao trabalho, prejudicados principalmente pela dor aos esforços de pronação e supinação.

A posição do punho artrodesado foi de extensão (média: 14,2) e desvio ulnar (média: 8,7 ), dentro da faixa de adequação para a maior parte das atividades profissionais e que proporciona maior força de preensão, segundo estudos biomecânicos ${ }^{(11,13,16,20)}$. Nos casos de artrodese bilateral, um dos punhos foi fixado em extensão e o outro em posição neutra, que facilita algumas atividades, como a higiene íntima, por exemplo.

A taxa de consolidação foi de $98 \%$ e o único caso que evoluiu com pseudartrose foi re-operado, obtendo-se a consolidação. 0 tempo médio de consolidação da artrodese foi de 8,16 semanas, período situado dentro do que é relatado na literatura ${ }^{(2,17)}$. Vale lembrar que a avaliação exata do tempo de consolidação é muito difícil na artrodese do punho, porque a própria constituição dos ossos envolvidos, predominantemente esponjosos, e a presença da placa constituem-se em obstáculos à perfeita visualização da área operada. Também, não houve diferença significativa entre a fixação rígida, com uma placa DCP, e outra mais elástica, com uma placa semitubular, o que se contrapõe à observação anterior, de que o tempo de consolidação foi ligeiramente mais longo com esta última (2).

A goniometria revelou que não houve comprometimento importante do cotovelo e do ombro, decorrente de procedimento cirúrgico. Apenas nos pacientes com patologias extra carpal, como as neuromusculares, observou-se incapacidade significativa para a prono-supinação, numa deficiência inerente à própria patologia.

A força de preensão da mão estava diminuída em quase todos os pacientes, com a média de $61,21 \%$ da força da mão contralateral normal, mas com uma variação muito ampla, vis- most of professional activities and allowing a better hand grip strength according to biomechanical studies ${ }^{(11,13,16,20)}$. In the case of bilateral arthrodesis, one of the wrists was fixed in extension and the other one in neutral position, making easier to perform some activities, such as private hygiene, for example.

Healing rate was of $98 \%$, and the only case which evolved to pseudarthrosis was resubmitted to surgery, getting to heal. Average time to bone healing of the arthrodesis was 8.16 weeks, which is in accordance with the reported in literature ${ }^{(2,17)}$. It is worthy to remind that it is very difficult to access exactly the time for healing of the arthrodesis, because the constitution of the involved bones, mostly cancellous, and the presence of the plate, constitute themselves as obstacles for a good observation of the healing area. There was also no significant difference between results of a rigid fixation, with a DCP plate, or a more elastic one with a semi-tubular plate, what opposes to the anterior observation, that healing time as slightly longer with the last one ${ }^{(2)}$.

Goniometry demonstrated that no important commitment of elbow or shoulder due to surgical procedure occurred. Only in patients with extra-carpal pathologies, such as neuromuscular ones, it was found a significant impairment of prono-suppination, in a deficiency inherent to the disease itself.

Grip strength was reduced in almost all patients, with an average of $61.21 \%$ of the strength of contralateral normal hand, however with a very wide range, since it was normal (100\%) in at least one patient, while it was almost null (7.2\%) in another one, with extracarpal neuromuscular disease, the group of patients with worst functional results. Jebsen's test ${ }^{(10)}$ revealed that the overall functional performance was of $71.70 \%$ of contralateral side, while Buck-Gramcko's(4) reached an average of 6.79 points, again the worst performance for extracarpal diseases. Obviously the deficiency in these cases was caused by the pathology and not by the arthrodesis. Yet, in the item personal satisfaction, all patients were unanimous to say that a functional improvement was achieved, or, at least, there was no worsening.

Complication rate was high in this set of cases. So, five had superficial infection which however resolved with specific treatment. A probable predisposing factor to superficial infection is the superficiality of the procedure and the plate, placed almost subcutaneously. Another probable factor is that the surgery was performed by training residents, what makes the surgery longer and increases tissue manipulation, as these events characterize the beginning of the learning curve. As experience increases, these factors trend to reduce their importance.

Surgical revision was necessary in three cases presenting complications linked to fixation leading to non healing. In these cases, it was always detected a technical mistake, also included in the learning procedure of residents, still not skilled in the surgery, and in the particularities of transarticular fixation, mainly regarding adequate preparation of the surfaces to be arthrodesed. In this case, again, the incidence of these complications should subside as a doctors become more experienced.

Carpal tunnel syndrome happened in one case, probably due to the sudden change in position of the wrist, partially flexed, to an extension of $20^{\circ}$. This is an unexpected and as well unpredictable, 
to que estava normal (100\%) em pelo menos um paciente, ao passo que foi quase nula $(7,2 \%)$ em outro, acometido de patologia extracarpal neuromuscular, que foi o contingente de pacientes com o pior desempenho funcional. O teste de Jebsen ${ }^{(10)}$ mostrou que o desempenho funcional global foi de $71,70 \%$ do lado contralateral, enquanto que o teste de Buck-Gramcko(4) atingiu a média de 6,79 pontos, novamente com o pior desempenho para as patologias extracarpais. Obviamente, a deficiência nesses casos era causada pela patologia e não pela artrodese. Já no quesito da satisfação pessoal, todos foram unânimes em afirmar que houve melhora funcional ou, no mínimo, não houve piora.

A taxa de complicações foi elevada nesta série de casos. Assim, cinco apresentaram infecção superficial, que, todavia, cedeu com o tratamento específico. Um provável fator predisponente da infecção é a superficialidade do procedimento e da placa, que aloja-se praticamente no espaço subcutâneo. Outro provável fator é a cirurgia realizada por residentes em treinamento, o que alonga o ato operatório e aumenta a manipulação tecidual, eventos que caracterizam o início da curva de aprendizado. Com o ganho de experiência, esses fatores tendem a diminuir sua importância.

A revisão cirúrgica foi necessária em três casos que apresentaram alguma complicação para o lado da fixação, evoluindo para a não consolidação. Nesses casos, detectou-se sempre um erro técnico, que se enquadra também no problema do aprendizado do médico residente, ainda pouco afeito à operação e às particularidades da fixação transarticular, principalmente no concernente ao preparo adequado das superfícies articulares a serem artrodesadas. Nesse caso, igualmente, a incidência dessa complicação deve diminuir com o ganho de experiência do médico.

A síndrome do túnel do carpo ocorreu num caso, provavelmente pela brusca mudança de posição do punho, de parcialmente fletido para a extensão de $20^{\circ}$. Esta já é uma complicação inesperada e imprevisível, visto ter sido observada em apenas um caso, que, todavia, evoluiu bem com a liberação cirúrgica do nervo mediano.

Cinco pacientes solicitaram a remoção da placa de osteossíntese. Esta é, de fato, motivo de queixas freqüentes dos pacientes, quer pelo aspecto estético, visto que a placa é visível sob a pele, quer pelo problema da dor ocasionada por traumatismos banais sobre ela. A provável solução desse problema é a placa especificamente desenhada para artrodese do punho, recentemente introduzida no mercado brasileiro pela $\mathrm{AO}$.

\section{CONCLUSÕES}

Apesar da taxa relativamente alta de complicações, devidas provavelmente à inexperiência de alguns dos cirurgiões, a conclusão tirada da análise dos casos aqui estudados é que a artrodese do punho com fixação interna rígida é um procedimento eficiente, de fácil execução, com resultados funcionais encorajadores, trazendo satisfação aos pacientes, mas que tem indicações muito precisas, não devendo ser indicada antes que outras possibilidades terapêuticas sejam aventadas. since it was found in only one case, which however had a good evolution after the median nerve was surgically released.

Five patients requested the plate to be removed. This is, as a matter of fact, the reason of frequent complaints of the patients, either for aesthetics, since the plate is visible under the skin, or for problems caused by minor traumas over it. The probable solution of this problem would be a specially designed plate for wrist arthrodesis recently introduced by $A O$ in Brazilian market.

\section{CONCLUSIONS}

Nevertheless a relatively high incidence of complications was found, probably due to inexperience of some of the surgeons, the conclusion from the analysis of the cases here presented is that wrist arthrodesis with a rigid internal fixation is an efficient procedure, which is easy to be performed, with encouraging functional results, bringing satisfaction to the patients, however with very precise indications. This surgery, however, should not be indicated before other therapeutic possibilities were evaluated.

\section{REFERÊNCIAS BIBLIOGRÁFICAS}

1. Abbot, L. C., Saunders, J. B. deC. \& Bost, F. C.: Arthrodesis of the wrist with the use of grafts of cancellous bone. J. Bone Joint Surg. 24: 883-898, 1942.

2. Barbieri, C. H., La Banca Jr., J. \& Sakashita, A. F.: Artrodese de punho com fixação interna rígida. Rev. Bras. Ortop. 22(6): 155-162, 1987.

3. Barbieri, C. H., Mazer, N., Kfuri Jr., M., Nishimura, M. T. \& Elui, V. M. C.: Artrodese do punho com fixação interna rígida: avaliação funcional. Rev. Bras. Ortop. 29(6):411-415, 1994.

4. Buck-Gramcko, D. \& Lohmann, H.: Compression arthrodesis of the wrist; in Tubiana, R. (ed.). The Hand (V. 2), Philadelphia, W. B. Saunders, 1981, p.723.

5. Campbell, C. J., Keokarn, T.: Total and subtotal arthrodesis of the wrist. J. Bone Joint Surg. 46A: 1520-1533, 1964.

6. Craigen, M. A. C. \& Stankley, J. K.: Distal ulnar instability following wrist arthrodesis in men. J. Hand Surg. 20B: 155-158, 1995.

7. Field, J., Herbert, T. J. \& Prosser, R.: Total wrist fusion. J. Hand Surg. 21B: 429-433, 1996. 8. Heim, U. \& Pfeiffer, K. M.: Small fragment set manual. Technique recommended by the ASIF group ( $2^{\text {nd }}$ ed.). Berlin, Heidelberg, New York, Springer-Verlag, 1982, p.143.

9. Hoppenfeld, S.: Physical examination of the spine and extremities. New York, Appleton-Century-Crofts, 1970, p.88-89.

10. Jebsen, R. H., Taylor, N., Trischmann, R. B., Trotter, M. J. \& Howard, L. A.: An objective and standardized test of hand function. Arch. Phys. Med. Rehab. 50: 311-319, 1969.

11. Kraft, G. H. \& Detels, P. L.: Position of function of the hand. Arch. Phys. Med. Rehab. 53: 272-275, 1972.

12. Larsson, S. E.: Compression arthrodesis of the wrist: a consecutive series of 23 cases. Clin. Orthop. 99: 146-153, 1974.

13. Leighton, R. K. \& Petrie, D.: Arthrodesis of the wrist. Can. J. Surg. 30: 115-116, 1987. 14. Mazzer N., Barbieri C. H., Martins M. M. P., Souza A. G.: Tratamento dos desarranjos da articulação radio-ulnal distal pela técnica de Sauvé-Kapandji. Resultados preliminaries. Acta Ortop. Bras. 9(1): 12-20, 2001.

15. Müller, M., Allgöwer, M., Schneider, R. \& Willenegger, H.: Manual of internal fixation ( $3^{\text {rd }}$ ed.), Berlin, Springer-Verlag, 1991, p.232.

16. Pryce, J. C.: The wrist position between neutral and ulnar deviation that facilites the maximum power grip strength.. J. Biomech. 13: 505-511, 1980.

17. Sagerman, S. D. \& Palmer, A. K.: Wrist arthrodesis using dynamic compression plate. J. Hand Surg. 21B: 437-441, 1996.

18. Taleisnik, J.: Subtotal arthrodesis of the wrist joint. Clin. Orthop. 187: 81-88, 1984. 19. Van Gemert, J. G. W. A.: Arthrodesis of the wrist. A clinical, radiographic and ergonomic study of 66 cases. Acta Orthop. Scand., Suppl. 210, V. 55, 1984.

20. Volz, R. G., Lieb, M. \& Benjamin, J.: Biomechanics of the wrist. Clin. Orthop. 149: 112-117, 1980.

21. Weiss, A-P. C. \& Hastings, H.: Wrist arthrodesis for traumatic conditions: a study of plate and local bone graft application. J. Hand Surg. 20A: 50-56, 1995.

22. Zachary, S. V. \& Stern, P. J.: Complications following AO-ASIF wrist arthrodesis. J Hand Surg, 20A: 339-344, 1995. 